next academic year. The Society also plans to sponsor the organization of model congresses in the high schools and round table conferences in the colleges and universities. In both instances, the Society will endeavor to encourage the discussion of current governmental problems. The Society's publications will not carry editorials, and the founders of the new organization aim to have all subjects treated in a non-partisan, impartial manner.

The Committee of the American Political Science Association on Basic Data and Statistics will be glad to receive suggestions for the improvement of existing summaries of political and governmental data. The prosecution of nearly every type of research leads the investigator to discover inadequacies in the categories used by official and private publications. It is the desire of the committee to serve as a clearing house for the proposals advanced by research workers and to consider the advisability of recommending some form of action which will carry these proposals into effect. It is believed that this may be established as one of the service functions of the Association. Communications may be addressed to the chairman or to any other member of the committee, i.e., Luther Gulick, National Institute of Public Administration; James Hart, Johns Hopkins University ; Harold D. Lasswell, chairman, University of Chicago.

Twenty-Seventh Annual Meeting of the American Political Science Association. The records show that the annual meeting held at the Mayflower Hotel, Washington, D.C., on December 28-30, 1931, was the most largely attended, and practically all persons present agreed that it was in other respects one of the most successful, in the history of the Association. The registered attendance was 353 , as compared with 317 at Cleveland in 1930, 127 at New Orleans in 1929, 235 at Chicago in 1928, and 292 in Washington in 1927. Most of the sessions took the form of round-table or section meetings, and the number and range of topies discussed strikingly evidenced the notable expansion and enrichment which political science as a discipline has experienced in recent years. A high point in the sessions was the report of the Committee on Policy, presented first to the Executive Council and afterwards to the business meeting of the Association by the chairman, Professor Thomas H. Reed, and printed (with additions showing various actions taken) on pp. 136149 below.

The program, in full, was as follows:

MONDAY, DECEMBER 28

10:00 A.M.

Round-Table Meetings.

1. Comparative Central Government-Economic Planning as a State Aotivity. 
PAPERS: “Economic Planning in Russia," George S. Counts, Columbia University.

"Economic Planning in Germany," Miriam E. Oatman, Brookings Institution.

"Economic Planning in Roumania," Joseph S. Roucek, Centenary Junior College.

Discussion: Bruce Hopper, Harvard University; George Kalusek, correspondent of the Narodni Politika, Prague; Lee S. Greene, University of Wisconsin; Leopold Sauer, Social Science Research Council Fellow.

2. Government and Education-Training Teachers of Government for the Public Schools.

PAPERS: Charles H. Judd, University of Chicago; George S. Counts, Columbia University.

DISCUSsion: William Anderson, University of Minnesota; Frank Bates, University of Indiana.

3. International Relations and Colonial Government-Problems of Colonial Administration and Legislation.

PAPER: Charles T. Loram, Yale University.

DIScUsSION : Rupert Emerson, Harvard University; H. D. Gideonse, University of Chicago; Amry Vandenbosch, University of Kentucky; Lennox Mills, University of Minnesota.

4. Judicial Administration-Administration of Federal Courts. DISCUSSION : Robert E. Cushman, Cornell University.

5. Local Government-Administrative Relations between the Cities and States. PAPERS: "The Point of View of the City," C. A. Dykstra, eity manager of Cincinnati.

"The Point of View of the State," John F. Sly, West Virginia University.

“European Experience," Roy V. Peel, New York University.

Drscussion: H. L. Lutz; Schuyler Wallace; Morris Lambie; T. H. Reed.

6. Political Parties-The Use of Money in Elections.

PAPER: "Voting Behavior as Related to Party Preference," Flora May Fearing, Northwestern University.

DIscussion : Harold F. Gosnell, University of Chicago.

12:30 P.M.

Subscription Luncheon.

Political Aspects of the New South.

CHAIRMAN : C. A. Dykstra, eity manager of Cineinnati.

PAPERS: "The Changing Background of Southern Politics," H. C. Nixon, Tulane University.

"Problems of Current Southern Politics," John W. Manning, University of Kentucky.

3:00 P.M.

\section{Section Meetings.}

1. Legislation-Research in Legislative Processes. INTRODUCTORY STATEMENT: John A. Lapp, Marquette University. PAPERS: "Research Work of the American Legislators' Association," Rodney L. Mott, University of Chicago. 
"The Legislative Interim Committee as a Legislative Research Agency," Martha Ziegler, Northwestern University.

"Power to Get the Facts," Charles W. Shull, College of the City of Detroit.

2. Public Opinion-A Reëxamination of the Public Opinion Concept.

PAPERS: "Language and the Newspaper," Kimball Young, University of Wisconsin.

"Quantitative Newspaper Analysis as a Technique of Opinion Research," Julian L. Woodward, Cornell University.

"Study of Interest Groups and Public Opinion," A. Gordon Dewey, Union College.

"Public Opinion and the Attribute Cluster-Bloc Technique," Herman C. Beyle, Syracuse University.

"Finding the Public," Peter Odegard, Ohio State University.

DIscussion : W. Y. Elliott, Harvard University.

3. Political Theory-The Place of Self-Regulating Economic Groups under a Democratio Government.

PAPERS: Dexter M. Keezer, the Baltimore Sun; John Dickinson, University of Pennsylvania Law School; Francis W. Coker, Yale University.

8:00 P.M.

General Session.

CHAIRMAN : B. F. Shambaugh, University of Iowa.

PRESIDENTIAT ADDRESS: "Social Planning Under the Constitution," Edward S. Corwin, Princeton University.

\section{TUESDAY, DECEMBER 29}

10:00 A.M.

\section{Round-Table Meetings.}

1. Comparative Central Government-Economio Planning as a State Activity.

PAPERS: “'National Economic Planning in France," André Bernard, Legislative Reference Service.

"Attempts at Centralized Planning in the United States," George B. Galloway, Editorial Research Reports.

"Some Social and Political Problems of Economic Planning," L. L. Lorwin, Brookings Institution.

DISCUSSION.

2. Government and Education-Methods of Teaching Government in the Schools.

PAPERS: J. B. Edmondson, University of Michigan; J. A. Engleman, Kent State College, Ohio.

Discussion: Ben Arneson, Ohio Wesleyan University; George J. Jones, Central High School, Washington, D.C.; Karl F. Geiser, Oberlin College.

3. International Relations and Colonial Government-International Political Effects of High Tariff.

PAPER: Philip G. Wright, Brookings Institution.

DISCUssion: Lynn R. Edminster, U. S. Department of Agriculture; H. B. Elliston, Christian Science Monitor; David Mitrany, Harvard University. 
4. Judicial Administration-Research in Judioial Administration. chamiman: Raymond Moley, Columbia University. PAPERS: J. A. C. Grant, University of California at Los Angeles, and Rodney L. Mott, University of Chicago.

5. Local Government-T'he Reorganization of Rural Areas. PAPERS: "Rural Areas," Theodore B. Manny, U. S. Department of Agriculture.

"Administrative Difficulties in Connection with Funetions in Onondaga County, New York," Robert F. Steadman, Syracuse University.

"The Sociological Implications of Rural Local Government," John H. Kolb, University of Wisconsin. Discussion: Wylie Kilpatrick, Trenton, New Jersey.

6. Political Parties-The Use of Money in Elections.

PAPERS: "Election Administration in its Relation to the Cost of Campaigning," Joseph P. Harris, University of Washington.

"Some Suggestions from British Practice for Regulating Election Expenditures,' James K. Pollock, University of Michigan.

DISCUSSION : Ralph S. Boots, University of Pittsburgh; Carroll H. Wooddy, University of Chicago.

7. Political Aspects of the New South-The Background of Southern Politics. DISCUssion: Robert S. Rankin, president of the Southern Political Science Association, Duke University.

12:30 P.M.

Subscription Luncheon.

Chatrman: Edward S. Corwin, Princeton University.

ADDRess: "Bringing the Government and the People Closer Together," David Lawrence, editor of the United States Daily.

Report of the Committee on Policy, Thomas H. Reed, University of Michigan, chairman.

$2: 30$ P.M.

Joint Meeting with the American Economic Association.

Investments and National Policy of the United States in Latin America. 4:00 P.M.

Annual Business Meeting.

\section{WEDNESDAY, DECEMBER 30}

10:00 A.M.

Round-Table Meetings.

1. Politicnl Parties-The Use of Money in Elections.

PAPERS: " $\Lambda$ Program for Public Regulation of Campaign Funds," Senator Bronson Cutting of New Mexico.

"The Kohler Case as an Illustration of Enforcement Difficulties," J. A. Clifford Grant, University of California at Los Angeles.

DISCUSSION: Senator Gerald Nye of North Dakota; Representative Robert Luce of Massachusetts.

2. Government and Education-The Place of Government in the Pubtic Sohool Curriculum.

PAPERS: F. J. Kelley, Office of Education, United States Department of the Interior; S. E. Ellett, Grand Rapids High School, Michigan. 
Discussion : J. P. Senning, University of Nebraska; John Lapp, Marquette University; Earl W. Crecraft, University of Akron.

3. Joint Meeting with the American Statistical Association.

Political Science and Statistics.

$12: 30$ P.M.

Subscription Luncheon.

CHAIRMAN: Miss Belle Sherwin, president of the National League of Women Voters.

ADDRESSES: "The Irish Free State," Hon. Michael MacWlite, minister of the Irish Free State to the United States.

"China Today," Hon. W. W. Yen, minister of the Chinese Republic to the United States.

$2: 30$ P.M.

Section Meetings.

1. Public Administration-The Findings of the Minnesota Conference on University Training for the Federal Service.

Presentation of the proceedings of the Conference by William Anderson and Morris B. Lambie, University of Minnesota.

Discussion of "Next Steps," L. J. O'Rourke, director of research of the United States Civil Service Commission.

DISCUSSION: Leonard White, University of Chicago and the Chicago Civil Service Commission; Harvey Walker, Ohio State University; Secretary of the Interior R. L. Wilbur; President T. E. Campbell of the United States Civil Service Commission; W. H. McReynolds, director of the Federal Personnel Classification Board.

2. Joint Meeting of the Section on Public Law with the American Association for Labor Legislation.

Effects of Administrative Law on Theory and Practice.

3. The Teaching of Government-The Teaching of the General Course in Political Scienoe.

PAPERS: "Government '21' at Columbia," Schuyler C. Wallace and A. Gordon Dewey, Union College.

"Government ' 1 ' at Harvard," George C. S. Benson.

"Political Science '1-2' at Michigan," James K. Pollock.

"Political Science '1-2' at Minnesota," William Anderson and O. P. Field.

"Political Science '104' at Wellesley" Louise Overacker.

"Political Science '1-2' at Williams," Donald C. Blaisdell.

"Political Science ' 1 ' at Wisconsin," John D. Lewis.

DISOUSSION.

The Secretary-Treasurer reported a total membership of 1,894, composed as follows : life members, 46 ; annual, sustaining, and associate members, 1,848. Of the last number, about 600 are libraries. A total of 226 new members were reported for the year 1931, the largest number ever aequired. in a single year.

The following balance sheet, operating account, and trust fund account for the fiseal year ending December were presented by the SecretaryTreasurer: 
Cash

In Bank-Checking Account ........ 601.60

In Bank-Trust Fund ............ 805.46

Petty Cash ................... $\quad 4.71$
$\$ 524.02 \$-77.58$
$910.64+105.18$
$.36 \quad-4.35$

Investments

U. S. Treasury Bonds . . . . . . . . 1,535.29

$1,535.29$

Comparison

with 1930

\begin{tabular}{|c|c|c|c|}
\hline & $\$ 2,947.06$ & $\$ 2,970.31$ & $\$+23.25$ \\
\hline iabilities & None & None & \\
\hline Cash Net Worth of the Association & $. \$ 2,947.06$ & $\$ 2,970.31$ & $\$+23.25$ \\
\hline
\end{tabular}

Cash on deposit December 15, 1930 805.46 Interest Received:

U. S. Securities

Bank Balances ............................... 3.91

105.18

Cash on deposit December 15, 1930

910.64

Comparative Statement of Income and Expenses for the Fiscal Years Which Ended December 15, 1930 and 1931 (and Estimates of Income and Expenses for the Fiscal Year Which Will End December 15, 1932).

Income

Year Ended D 15,1930

Current dues collected from old members ...... $\$ 6,068.59 \$$

Current dues collected from new members ..... 403.75

Prepaid dues collected ... $\quad \mathbf{8 1 0 . 5 0}$

Lelinquent dues collected 220.75

Total dues ............

Special contributions ....

Sale of publications .....

Sale of indices ..........

Sale of mailing lists ....

Sale of special reprints ..

Total sales ...........

Advertising ...........

Royalties ............

Interest
$7,503.59$

135.00

245.09

8.00

48.00

64.04

365.13

429.47

2.05

67.28
$\$ 5,939.50 \$$

950.17

902.75

230.00

$15,19 \$ 1$

Estimates for the

Year to end Dec.

$$
\text { 15, } 1992
$$


Expenses

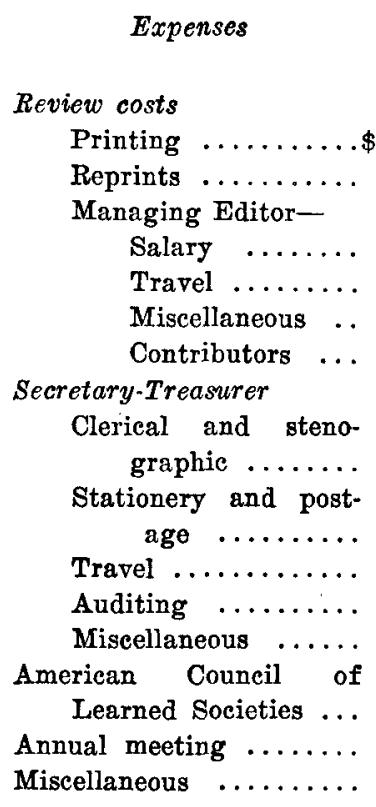

Deficit for the year .....

Surplus for the year....
Year Ended Dec. 15,1930
15,1931
Estimates for the

Year to end Dec. 15,1938

\begin{tabular}{rr}
$\$ 5,162.55$ & $\$$ \\
372.83 & \\
600.00 & \\
125.88 & \\
692.00 & \\
388.34 & $7,341.60$ \\
& \\
900.00 & \\
258.56 & \\
284.91 & \\
39.50 & \\
138.08 & $1,621.05$ \\
& 45.00 \\
& 194.35 \\
& 343.52 \\
\hline$\$ 9,545.52$ \\
$\frac{1,045.05}{\text { None }}$ \\
\end{tabular}

$\$ 5,281.31$
300.03

600.00

50.55

703.00

$358.50 \quad 7,293.39$

$\$ 5,200.00 \$$
300.00

600.00

80.00

650.00

$370.00 \quad 7,200.00$

900.00

900.00

230.55

82.33

43.32

122.55

230.00

100.00

50.00

$75.00 \quad 1,355.00$

45.00

45.00

170.00

138.60

180.00

183.93

\begin{tabular}{c}
$\overline{\$ 9,039.67}$ \\
\hline $\begin{array}{c}\text { None } \\
23.25\end{array}$
\end{tabular}

$\overline{\$ 8,950.00}$

None

None

At the annual business meeting, the following officers of the Association were elected for the year 1932: president, W. F. Willoughby, Brookings Institution, Washington, D.C.; first vice-president, Leonard D. White, University of Chicago; second vice-president, Ellen D. Ellis, Mt. Holyoke College ; third vice-president, P. Orman Ray, University of California; secretary-treasurer, Clyde L. King, University of Pennsylvania; members of the Executive Council for the term ending December 31, 1934: Thomas S. Barclay, Stanford University; James Hart, Johns Hopkins University; Morris B. Lambie, University of Minnesota ; Kirk H. Porter, University of Iowa; and Frank M. Stewart, University of Texas.

Final action was taken on the proposal to convert the REviEw into a bi-monthly, and the new schedule goes into effect with the current issue. On recommendation of the Managing Editor, a plan was adopted under which, beginning in 1932, members of the Board of Editors will be elected for two-year terms, one-half retiring at the close of each year. With a view to putting the system into operation, five present members of longest service-C. A. Berdahl, R. E. Cushman, A. C. Hanford, T. H. 
Reed, and C. L. King-were reëlected for one year, and five of shorter service-W. F. Dodd, A. W. Macmahon, C. W. Pipkin, R. M. Story, and L. D. White-for two years.

At the close of the meeting it was announced that the chairman of the committee on program for the 1932 meeting will be Morris B. Lambie, of the University of Minnesota. Round-tables were asked, as a year ago, to designate representatives to coöperate with the committee in planning the program.

Some discussion in the Executive Council of the place of meeting in 1932 brought out support chiefly for Detroit, Cincinnati, and Columbus. Decision, however, remains to be made by the Council, and will be announced in an early issue of the REvnew. There is a possibility that a special meeting will be arranged for the summer of 1933 in connection with a proposed international congress of the social sciences to be held at Chicago during the Century of Progress Exposition.

Clyde L. KING, Secretary-Treasurer.

Report of the General Chairman of the Committee on Policy for the Year 1931. The Standing Committee on Policy was organized in accordance with a resolution adopted by the Association at its annual business meeting on December 30, 1930. In addition to the General Chairman, its membership for the past year has been as follows:

Appointed members

Subcommittee on Research

Subcommittee on Publications

W. F. Willoughby

B. F. Shambaugh

Charles A. Beard

Charles E. Merriam

Arthur N. Holcombe

Isidor Loeb

Subcommittee on Personnel

William Anderson

Subcommittee on Political

Education

Luther Gulick

Harold W. Dodds

Harvey Walker

William B. Munro

Earl W. Crecraft

Ex-officio members

President Edward S. Corwin (Subcommittee on Research)

Secretary Clyde L. King (subcommittee on Research)

Editor Frederic A. Ogg (Subcommittee on Publications)

The terms of Charles E. Merriam, Harvey Walker, Isidor Loeb, and Earl W. Crecraft expired with the annual meeting of 1931. Incoming President W. F. Willoughby designated Edward S. Corwin to fill out the remainder of the former's appointive term, reappointed Charles $\mathbf{E}$. 